\title{
ŽURNĀLISTA JĒDZIENS TIESĪBU UZ ŽURNĀLISTU INFORMĀCIJAS AVOTU AIZSARDZĪBU KONTEKSTĀ
}

\section{DEFINING JOURNALIST IN THE CONTEXT OF PROTECTING INFORMATION SOURCES}

\author{
Linda Bīrina, $M g$. iur. \\ Zvērināta advokāte \\ Latvijas Universitātes Juridiskās fakultātes doktorante
}

\section{Summary}

The right to protect information sources is a privilege that has been granted to journalists. Thus, the definition of who is a journalist needs to be considered in this context. The article strives to determine criteria that can be applied in order to define journalist. While it is acknowledged that journalists working in the traditional media are entitled to this privilege, the important role that bloggers and citizen journalists play in the gathering and dissemination of information should also be taken into account. Therefore, the Council of Europe has proposed Member States to apply a functional definition of journalist, defining it as any person who is regularly or professionally engaged in the collection and dissemination of information to the public via any means of mass communication.

Atslēgvārdi: žurnālists, blogeris, avotu aizsardzība

Keywords: journalist, blogger, source protection

\section{Ievads}

Žurnālista loma un mērķis demokrātiskā sabiedrībā, ievērojot robežas attiecībā uz citu cilvēku reputāciju un tiesībām, ir dalīties ar informāciju un idejām par visiem sabiedriski nozīmīgiem jautājumiem. ${ }^{1}$ Žurnālista tiesības informēt sabiedrību izriet no tiesībām uz vārda brīvību, un žurnālista kā "sabiedrības sargsuṇa” (angl̦u val. - public watchdog) lomai ir izšḳiroša nozìme demokrātiskā sabiedrībā. ${ }^{2}$

Kaut arī ikvienai personai ir tiesības uz vārda brīvību, tomēr ne visām personām ir piešķirtas īpašas privilēgijas šo tiesību īstenošanā, piemēram, attiecībā uz piekḷuvi informācijai vai personas datu apstrādi žurnālistiskām vajadzībām.

1 ECT 07.02.2012. spriedums lietā Axel Springer AG v. Germany (iesnieguma Nr. 39954/08), 79. punkts.

2 ECT 23.09.1994. spriedums lietā Jersild v. Denmark (iesnieguma Nr. 15890/89), 31. punkts; Van Dijk P., Van Hoof F., Van Rijn A., Zwaak L. (eds.). Theory and Practice of the European Convention on Human Rights. $4^{\text {th }}$ ed. Antwerpen, Oxford: Intersentia, 2006, p. 775. 
Līdz ar to žurnālisti ir jānoškiir no pārējām personām, kurām ir tiesības uz vārda brīvību, jo žurnālistu tiesību uz vārda brīvību robežas ir daudz plašākas. ${ }^{3}$ Starp būtiskākajām žurnālistu privilègijām ir tiesības neizpaust savus informācijas avotus. ${ }^{4}$ Tiesības uz žurnālistu informācijas avotu neaizskaramību ir viens no pamata apstākḷiem preses brīvības nodrošināšanai, jo bez šādas aizsardzības avoti varētu nevēlēties sniegt palīdzību presei, lai informētu sabiedrību par to interesējošiem jautājumiem. ${ }^{5}$ Tādējādi šo tiesību îstenošanas kontekstā ir svarīgi izvērtēt žurnālista jēdzienu.

Šì raksta pirmajā nodaḷā tiks aplūkotas žurnālista definēšanas teorijas un žurnālista jēdziens Eiropas Cilvēktiesību un pamatbrīivibu aizsardzības konvencijas izpratnē, lai konstatētu, kādas personas atbilst žurnālista statusam un varētu paļauties uz privilēgiju neizpaust savus informācijas avotus. Savukārt otrajā nodạ̣ā tiks apskatìta žurnālista definīcija Latvijā, un ar salīdzinošās metodes palīdzību, vispārīgi izvērtējot arī atsevišķu citu Eiropas Padomes un Eiropas Savienības dalībvalstu (Vācijas, Apvienotās Karalistes, Francijas, Somijas, Dānijas, Beḷgijas, İrijas, Slovēnijas) pieeju attiecībā uz žurnālista definēšanu, kā arī, nnemot vērā pirmajā nodạ̦ā secināto, autore sniegs ierosinājumus nepieciešamajām izmaiņām Latvijas regulējumā.

\section{Žurnālista definēšanas teorijas un žurnālista jēdziens Eiropas Cilvēktiesību un pamatbrīvību aizsardzības konvencijas izpratnē}

No juridiskā viedokḷa pastāv divas galvenās žurnālistu definēšanas teorijas institucionālā un funkcionālā. ${ }^{6}$ Atbilstoši institucionālajai teorijai par žurnālistu tiek uzskatīta persona, kas ir ieguvusi žurnālista izglìīibu, strādā kādā medijā vai ir piederīga profesionālajai organizācijai. ${ }^{7}$ Praksē komplicētāka pieeja ir funkcionālajai teorijai, saskaņā ar to par žurnālistu tiek uzskatīta ikviena persona, kas veic žurnālistam raksturīgās funkcijas un pienākumus. ${ }^{8}$

Tās personas, kuras atbilst žurnālista statusam saskaņā ar institucionālo teoriju, pārsvarā būtu uzskatāmas par žurnālistiem arī atbilstoši funkcionālajai teorijai, līdz ar to šādos gadỉjumos atšķirība starp abām teorijām nav tik būtiska. Taču neskaidrība rodas situācijās, kad persona nestrādā medijā, nav žurnālistu organizāciju biedrs, bet veic žurnālistiem raksturīgās funkcijas. Funkcionālās definīcijas pamatā ir pieṇēmums, ka mūsdienās tehnologiiju attīstība pavērusi neierobežotas iespējas iegūt un izplatīt informāciju, tādēl ikviens, it īpaši jau blogeri, var dot pienesumu sabiedriskajā diskusijā, veicinot demokrātijas attīstību. ${ }^{9}$

Galvenais risks, piemērojot funkcionālo teoriju, ir noteikt pārāk plašu to personu loku, kurām tiktu piešķirtas žurnālistiem raksturīgās privilēgijas, attiecīgi

\footnotetext{
Susi M. Human Rights, Digital Society and the Law: A Research Companion. Abingdon, Oxon [UK], New York, NY: Routledge, 2019.

4 ECT 27.03.1996. spriedums lietā Goodwin v. the United Kingdom (iesnieguma Nr. 17488/90), 39. punkts.

5 Ibid.

6 Rowbottom J. Media Law. Oxford, UK: Hart Publishing, 2018, pp. 27-31; Šimkus A. Žurnālista un avotu aizsardzības privilēgijas definīcija Eiropā un ASV. Jurista Vārds, 2016, Nr. 37, 10.-17. lpp.

7 Šimkus A. 2016, 10.-17. lpp.

8 Rowbottom J. 2018, p. 30; Simkus A. 2016, 10.-17.lpp.

9 Article 19: The Right to Blog. Pieejams: https://www.article19.org/data/files/medialibrary/3733/Rightto-Blog-EN-WEB.pdf [aplūkots 06.03.2020.].
} 
ir rūpīgi jāapsver, kā definēt žurnālistikas funkcijas. ${ }^{10}$ Žurnālistiem raksturīgās funkcijas tradicionāli ietver informācijas vākšanu, ziṇu gatavošanu, sabiedrības informēšanu par tai svarīgiem un to interesējošiem jautājumiem un tamlīdzīgi. Savukārt būtiskākais pienākums ir ievērot profesionālo ètiku un atbildību. ${ }^{11}$ Vienlaikus Eiropas Savienības Tiesa (turpmāk - EST) vismaz attiecībā uz personas datu apstrādi žurnālistiskām vajadzībām savā praksē žurnālistikas darbības ir definējusi l̦oti plaši.

Saskaņā ar EST praksi žurnālistikas darbības attiecas uz tādu rīcību, kuras vienīgais mērḳis ir sniegt sabiedrībai informāciju, viedokḷus vai idejas ar jebkāda izplatī̌sanas līdzekḷa palīdzību. ${ }^{12}$ Kā atzinusi EST, pat situācija, kad policijas darbinieki tiek filmēti policijas iecirknī paskaidrojumu pieņemšanas laikā un šādi veiktais videoieraksts tiek publicēts interneta vietnē, kurā lietotāji var nosūtīt un apskatīt videoierakstus un dalīties ar tiem, var būt personas datu apstrāde tikai žurnālistikas nolūkiem, ja no minētā videoieraksta izriet, ka tā filmēšanas un publicēšanas vienīgais mērķis bija publiskot informāciju, viedokḷus vai idejas. ${ }^{13}$ Tādējādi EST vērsa uzmanību uz to, ka apstāklis, ka persona tradicionāli nav žurnālists, neizslēdz žurnālistikas funkciju attiecināšanu uz viṇu, kā arī apstāklis, ka informācija ir izplatīta netradicionālā veidā, proti, interneta vietnē www.youtube.com, nevar liegt to kvalificèt kā tādu, kas veikta tikai "žurnālistikas nolūkiem”. Lìdz ar to indivīdu, kas nodarbojas ar tā dēvēto "pilsonisko žurnālistiku”, vācot un izplatot informāciju, lai varētu publiskot informāciju, viedokḷus vai idejas, var uzskatīt par personas datu apstrādātāju žurnālistikas nolūkiem. ${ }^{14}$ Autores ieskatā EST pieeja tomēr neḷauj pietiekami nošķirt, vai persona rīkojas žurnālistikas nolūkos, vai arī tā ir cita veida komunikācija, piemēram, īstenojot tiesības uz vārda brīvību sociālajos medijos, kas piemìt ikvienai personai un var tikt izmantota arī ārpus žurnālistikas nolūkiem.

Eiropas Cilvēktiesību un pamatbrīvību aizsardzības konvencijas ${ }^{15}$ (turpmāk Konvencija) 10. pants paredz ikvienam tiesības brīvi paust savus uzskatus, tās ietver tiesības netraucēti saņemt un izplatīt informāciju un idejas. Eiropas Cilvēktiesību tiesa (turpmāk - ECT) savā praksē nav tieši noteikusi, kādas personas var uzskatīt par žurnālistiem saskaņā ar Konvencijas 10. pantu, taču no ECT prakses ir iespējams secināt, ka ECT atbalsta ne tikai institucionālo, bet arī funkcionālo pieeju žurnālista statusa noteikšanai. ${ }^{16}$ Interpretējot Konvencijas 10. pantu, ECT ir pat norādijjusi, ka lietotāju izteikšanās internetā rada nepieredzētu vārda brīvības platformu un ziṇu un komentāru publicēšana interneta vietnē ir žurnālistikas darbība. ${ }^{17}$ ECT ir arī atzinusi, ka dažādu "sabiedrisko debašu platformu radīšanas” funkcija nepiemīt tikai tradicionālajai presei.

10 Rowbottom J. 2018, p. 30.

11 Ibid., p. 29.

12 EST 16.12.2008. spriedums lietā C-73/07 Satakunnan Markkinapörssi and Satamedia, 61. un 62. punkts.

13 EST 14.02.2019. spriedums lietā C-345/17 Buivids, 69. punkts.

${ }^{14}$ G̦enerāladvokātes Eleanoras Šarpstones (Eleanor Sharpston) 27.09.2018. secinājumi EST lietā C-345/17, Buivids, 53. punkts.

${ }^{15}$ Cilvēka tiesību un pamatbrīvību aizsardzības konvencija. Parakstīta Romā 04.11.1950. [01.06.2010. red.].

16 Sk., piemēram: ECT 27.03.1996. spriedums lietā Goodwin v. the United Kingdom (iesnieguma Nr. 17488/90); ECT 15.02.2005. spriedums lietā Steel and Morris v. the United Kingdom (iesnieguma Nr. 68416/01); ECT 27.05.2004. spriedums lietā Vides Aizsardzības Klubs v. Latvia (iesnieguma Nr. 57829/00).

17 ECT 16.06.2015. spriedums lietā Delfi AS v. Estonia (iesnieguma Nr. 64569/09), 110., 112. un 113. punkts. 
Turklāt, ņemot vērā interneta būtisko lomu, lai paplašinātu sabiedrības piekḷuvi ziņām un veicinātu informācijas izplatīšanu, blogeru un populāru sociālo mediju lietotāju funkcija var tikt pielīdzināta "sabiedrības sargsuṇa” lomai, ciktāl ir runa par Konvencijas 10. pantā piešķirto aizsardzību. ${ }^{18}$

1996. gadā ECT pirmo reizi konstatēja, ka Konvencijas 10. pants ietver žurnālistu tiesības neizpaust savu informācijas avotu. ${ }^{19}$ Jau šajā lietā ECT žurnālista privilēgijas attiecināja uz personu, kura stažiera statusā bija nostrādājusi izdevniecībā trīs mēnešus. ${ }^{20}$ Savukārt 2000. gadā Eiropas Padomes Ministru komiteja pieṇēma Rekomendāciju dalībvalstīm Nr. 7 (2000) "Par žurnālistu tiesībām neatklāt informācijas avotus"21 (turpmāk - Rekomendācija), kas nodrošina pamatu kopīgiem minimāliem Eiropas standartiem attiecībā uz žurnālistu tiesībām neizpaust savus informācijas avotus Konvencijas 10. panta izpratnē. Atbilstoši Rekomendācijai termins “žurnālists” apzīmē jebkuru fizisku vai juridisku personu, kas regulāri vai profesionāli iesaistīta informācijas vākšanā vai izplatīšanā sabiedrībai ar jebkuriem masu sazinas līdzekḷiem.

Kaut arī parasti žurnālists ir fiziska persona, tomēr Rekomendācijā kā “žurnālisti” tiek aizsargātas arī juridiskas personas, piemēram, mediji, izdevniecības, ziṇu aǵentūras, kuru rīcībā var būt informācijas avotu sniegtā informācija. No Rekomendācijā ietvertās žurnālista definīcijas varētu secināt, ka regulāra vai profesionāla darbība masu saziņas līdzeklī ir priekšnosacījums žurnālista statusa iegūšanai, taču Rekomendācijas paskaidrojošais memorands izskaidro, ka šìs definīcijas piemērošana nedrīkst izslēgt ārštata vai uz nepilnu slodzi nodarbinātus žurnālistus vai tos, kas tikko sākuši profesionālo karjeru vai kādu laiku nodarbojas ar kādu neatkarīgu pētījumu. ${ }^{22}$ Tāpat arī norādīts, ka žurnālista statusa iegūšanai nav nepieciešama profesionāla akreditācija vai noteikta biedrība. Taču par žurnālistu nevarētu uzskatīt tādas personas, kas raksta vēstules drukātā medija redaktoram, piedalās kā viesi radio un televīzijas pārraidēs vai iesaistās interneta mediju diskusiju forumos, jo avotu aizsardzība ir būtisks mediju darba priekšnoteikums demokrātiskā sabiedrībā, bet ne priekšnosacījums visām indivīdu komunikācijas formām. ${ }^{23}$

Attiecībā uz Rekomendācijas definīcijā ietverto norādi par masu saziņas līdzekḷu starpniecību informācijas vākšanā vai izplatīšanā memorandā paskaidrots, ka var tikt izmantota jebkura komunikācijas tehnika, ieskaitot neperiodiskas publikācijas un audiovizuālus darbus, kā rezultātā arī fotožurnālisti un interneta mediju žurnālisti tiek iekḷauti žurnālista jēdzienā. ${ }^{24}$ Tāpat arī memorandā norādīts, ka nav neviena argumenta, lai ierobežotu žurnālista jēdzienu tikai ar tādām personām, kuras pilda savus pienākumus tradicionālajos

${ }^{18}$ ECT 08.11.2016. spriedums lietā Magyar Helsinki Bizottság v. Hungary (iesnieguma Nr. 18030/11), 166. un 168. punkts.

${ }^{19}$ ECT 27.03.1996. spriedums lietā Goodwin v. the United Kingdom (iesnieguma Nr. 17488/90), 39. punkts.

20 Ibid.

${ }^{21}$ Recommendation No. R (2000) 7 of the Committee of Ministers to member states on the right of journalists not to disclose their sources of information. Council of Europe. Pieejams: https://search.coe. $\mathrm{int} / \mathrm{cm} /$ Pages/result_details.aspx?ObjectId=09000016805e2fd2 [aplūkots 06.03.2020.].

22 Explanatory Memorandum to Recommendation No. R (2000) 7 of the Committee of Ministers to member states on the right of journalists not to disclose their sources of information. Council of Europe. Pieejams: https://search.coe.int/cm/Pages/result_details.aspx?ObjectId=09000016805e2c13 [aplūkots 06.03.2020.].

23 Ibid.

24 Ibid. 
medijos, kā avīzēs, radio un televīzijā, aicinot dalībvalstis žurnālista jēdzienu attiecināt arī uz personām, kas profesionāli strādā, vāc un izplata informāciju arī ar tādiem jauniem komunikācijas līdzekḷiem kā internets.

Turklāt neatkarīgi no personas statusa ECT savā praksē ir noteikusi kritērijus, kādiem jāpiepildās, lai persona varētu baudīt tiesības un privilēǵijas, kas izriet no Konvencijas 10. panta. Pirmkārt, tā ir diskusijas veicināšana par sabiedrībai būtiskiem jautājumiem jeb sabiedrības interešu kritērijs. Tādējādi ne katra publicētā informācija atbilst sabiedrības interesēm un būtu aizsargājama. Otrkārt, žurnālistu tiesības izplatīt sabiedrības interesi raisošu informāciju prasa, lai viṇi rīkotos labā ticībā un balstītos uz patiesu faktisko situāciju, kā arī sniegtu uzticamu un precīzu informāciju saskaṇā ar žurnālistu ètikas standartiem. ${ }^{25}$ Minētie kritēriji ietilpst atbildīgas žurnālistikas konceptā, taču, kā atzinusi ECT, lai radītu vai veicinātu diskusiju par sabiedrībai nozīmīgiem jautājumiem, publicēt informāciju žurnālistikas nolūkos var jebkura persona. Attiecīgi personai, kura nav uzskatāma par žurnālistu, iesaistoties publiskā diskusijā, tieši tāpat ir jāievēro pienākums par precīzas un uzticamas informācijas sniegšanu, kā arī jārīkojas labā ticībā. ${ }^{26}$

Arī lietās, kuras ir bijušas saistītas ar tiesībām uz žurnālistu informācijas aizsardzību un kurās nebija šaubu par žurnālista statusu, ECT ņēma vērā, vai persona, kura atsaucas uz šo privilēgiju, ir rīkojusies atbilstoši iepriekš minētajiem atbildīgas žurnālistikas kritērijiem. ${ }^{27}$ Tādējādi žurnālista privilēgéijas nevarētu iegūt persona, kura nav rīkojusies atbilstoši šiem kritērijiem pat tad, ja persona saskaṇā ar institucionālo definīciju tradicionāli būtu uzskatāma par žurnālistu. ${ }^{28}$ Vienlaikus, ņemot vērā, ka atbildīgas žurnālistikas kritēriji ir jāievēro jebkurai personai, kura iesaistās publiskā diskusijā, nebūtu pamata personai piešķirt žurnālista statusu un informācijas avotu aizsardzības privilēgéijas, ja bez šiem kritērijiem nepastāvētu vēl kāds, kas ḷautu personu atzìt par žurnālistu atbilstoši funkcionālajai definīcijai, piemēram, Rekomendācijā norādìtā publicēšanās regularitāte vai atalgojuma saņemšana par savu darbu. Indivīdi, kas citos apstākḷos sevi neuzskatītu par žurnālistiem, nevar tikt kvalificēti kā tādi vismaz informācijas avotu aizsardzības kontekstā, ${ }^{29}$ tādēḷ žurnālista definīcijā ietverta norāde uz regulāru vai profesionālu iesaisti informācijas vākšanā vai izplatīšanā sabiedrībai. Attiecīgi Rekomendācijā ietvertā definīcija izslēdz tādus blogerus un pilsoniskos žurnālistus, kuri, kaut arī publicē informāciju, tomēr to nedara regulāri vai profesionāli. Minētais tiek pamatots ar to, ka šì profesionālā priviléğija

25 Flanagan A. Defining "journalism” in the age of evolving social media: a questionable EU test. International Journal of Law and Information Technology, 2012, Vol. 21, No. 1, pp. 1-30; ECT 15.12.2009. spriedums lietā Financial Times Ltd and Others v. the United Kingdom (iesnieguma Nr. 821/03), 62. un 67. punkts; ECT 04.11.2014. spriedums lietā Braun v. Poland (iesnieguma Nr. 30162/10), 40. punkts.

${ }^{26}$ ECT 04.11.2014. spriedums lietā Braun v. Poland (iesnieguma Nr. 30162/10), 40. punkts.

27 Sk., piemēram: ECT 12.11.2007. spriedums lietā Dupuis and Others v. France (iesnieguma Nr. 1914/02), 43. un 46. punkts; ECT 25.02.2003. spriedums lietā Roemen and Schmit v. Luxembourg (iesnieguma Nr. 51772/99), 54. punkts; ECT 15.12.2009. spriedums lietā Financial Times Ltd and Others v. the United Kingdom (iesnieguma Nr. 821/03), 67. punkts.

28 Rowbottom J. 2018, p. 30.

${ }^{29}$ Explanatory Memorandum to Recommendation No. R (2000) 7 of the Committee of Ministers to member states on the right of journalists not to disclose their sources of information. 
balstās uz konfidencialitātes un uzticības attiecībām, taču šādas attiecības nevar attiecināt uz jebkuru personu, kurai ir sava mājaslapa vai blogs. ${ }^{30}$

\section{Žurnālista definīcija Latvijā un atsevišķās Eiropas Padomes dalībvalstīs}

Latvijā žurnālista definīcija ir ietverta likumā "Par presi un citiem masu informācijas līdzekḷiem"31 (turpmāk - Preses likums), kura mērķis ir aizsargāt Latvijas Republikas Satversmē nostiprinātās tiesības uz vārda brīvību. Preses likuma 23. pantā ietverta definīcija, kuras pamatā ir institucionālā teorija. Saskaṇā ar minēto pantu "par žurnālistu šajā likumā tiek uzskatīta persona, kura vāc, apkopo, rediǵē vai citādā veidā sagatavo materiālus masu informācijas lìdzeklim un kura ar to noslēgusi darba līgumu vai veic šo darbu masu informācijas līdzekḷa uzdevumā, kā arī ir žurnālistu apvienību biedrs". Tādējādi Latvijā par žurnālistu, kuram piemīt Preses likumā noteiktās tiesības, būtu uzskatāma tikai tāda persona, kura savus profesionālos pienākumus veic masu informācijas līdzeklī vai tā uzdevumā, kā arī persona, kura ir žurnālistu apvienību biedrs. Attiecīgi personas, kuras veic tās pašas funkcijas, bet strādā individuāli, nav iestājušās nevienā žurnālistu apvienībā un sava darba rezultātus publicē blogā vai citā vietnē vai izdevumā, kas nav reǵistrēts kā masu informācijas līdzeklis, nebūtu uzskatāmas par žurnālistu un nevarētu iegūt tiesības neizpaust savu informācijas avotu. Šāda pieeja ir vērtējama kritiski, jo izslēdz iespēju noteikt personai žurnālista statusu, balstoties uz funkcionālās definīcijas kritērijiem. Arī Tiesībsarga birojs ir norādījis, ka sociālo paradumu izmaiņas padarỉjušas par neiespējamu aprobežot žurnālistikas jēdzienu vienīgi ar reglamentētas profesijas darbību. ${ }^{32}$

Nav šaubu par to, ka masu informācijas lìdzekḷi pastāvīgi mainās un tehnologijiju attīstības rezultātā rodas jaunas mediju formas. ${ }^{33}$ Vienlaikus likumdošanas process bieži ir lēns un netiek līdzi jauno mediju formu regulēšanai, savukārt žurnālisti, kuri savu pienākumu pildīšanai izmanto jaunākās tehnologijas, bieži ir mazāk pasargāti nekā viṇu kolẹgi tradicionālajos medijos. ${ }^{34}$ Lìdz ar to interneta un sociālo mediju parādīšanās ir izaicinājums vairākām definīcijām, kuras līdz šim ir noteikušas, kas ir žurnālists un attiecīgi kas var tikt aizsargāts. ${ }^{35}$ Apstākḷ,os, kad tradicionālās žurnālistikas formas ir mainījušās, žurnālista definēšanā ir jāpievēršas arī saturam un tā radīšanas metodēm. ${ }^{36}$ Jautājums par to, kas ir un kas nav žurnālists, ir skaidrāks valstīs, kur ir senas

${ }^{30}$ Recommendation 1950 (2011) of the Parliamentary Assembly on the protection of journalists' sources. Council of Europe. Pieejams: https://assembly.coe.int/nw/xml/XRef/Xref-XML2HTML-en. asp?fileid=17943\&lang=en [aplūkots 06.03.2020.].

31 Par presi un citiem masu informācijas līdzekl̦iem: LV likums. Pieņemts 20.12.1990. [13.02.2020. red.].

32 LR Tiesībsargs: Privātpersonas tiesības izplatīt sabiedrībai būtisku informāciju. Pieejams: http:// www.tiesibsargs.lv/news/lv/privatpersonas-tiesibas-izplatit-sabiedribai-butisku-informaciju [aplūkots 06.03.2020.].

${ }^{33}$ Recommendation CM/rec (2011) 7 of the Committee of Ministers to member states on a new notion of media. Council of Europe. Pieejams: http://www.osce.org/odihr/101403?download=true [aplūkots 06.03.2020.].

34 Banisar D. Silencing Sources: An International Survey of Protection and Threats to Journalistic Sources, p. 30. Pieejams: https://papers.ssrn.com/sol3/papers.cfm?abstract_id=1706688 [aplūkots 06.03.2020.].

35 Ibid., p. 31.

36 Rožukalne A. Sauciet mani par žurnālistu! Pieejams: http://providus.lv/article/sauciet-mani-parzurnalistu [aplūkots 06.03.2020.]. 
demokrātijas tradīcijas un sabiedrība zina, ka īpašas tiesības un aizsardzība ir saistīta arī ar pienākumiem un atbildību. ${ }^{37}$

Iepazīstoties ar regulējumu atsevišḳās Eiropas Padomes dalībvalstīs, kuras vienlaikus ir arī Eiropas Savienības dalībvalstis un pārstāv atšķirīgas juridiskās tradīcijas un tiesību sistēmas, secināms, ka vairākās no tām, piemēram, Vācijā un Apvienotajā Karalistē, žurnālista definīcija normatīvo aktu līmenī netiek sniegta. ${ }^{38}$ Savukārt valstīs, kurās normatīvie akti paredz žurnālista definīciju, piemēram, Francijā ${ }^{39}$ un Slovēnijā, ${ }^{40}$ kā arī valstīs, kurās žurnālista definīcija izriet no žurnālistu apvienību noteiktajiem kritērijiem, piemēram, Somijā ${ }^{41}$ un Dānijā, ${ }^{42}$ tās ir mēǵinājušas rast līdzsvaru starp institucionālo un funkcionālo pieeju.

Beḷgija žurnālistu informācijas avotu aizsardzības kontekstā citu Eiropas Padomes dalībvalstu vidū tiek pozitīvi izcelta saistībā ar to, ka tā ir pieṇēmusi speciālu likumu par žurnālistu avotu aizsardzību. Šis likums sākotnēji definēja žurnālistu kā jebkuru personu, kura strādā kā pašnodarbinātā vai algotā darbā un regulāri apkopo, rediǵē, sniedz vai izplata informāciju sabiedrībai ar mediju starpniecỉbu. Taču pēc Beḷgijas konstitucionālās tiesas sprieduma 2006. gadā ${ }^{43}$ tika veikti grozījumi likumā, izslēdzot no definīcijas norādi uz pašnodarbinātā vai algota darbinieka kritēriju, kā arī regularitātes kritēriju. Tiesas ieskatā minētie kritēriji žurnālista statusa un privilēǵiju iegūšanai ir pretrunā ar Beḷ́gijas konstitūcijā nostiprinātajām tiesībām uz vārda un preses brīvību, jo tiesības uz avotu aizsardzību ir jānodrošina nevis žurnālistiem kā profesijas pārstāvjiem, bet lai l̦autu medijiem pildìt savu "sargsuņa lomu” un informēt sabiedrību par jautājumiem, kas skar tās intereses. Attiecīgi tiesas ieskatā jebkura persona, kas veic žurnālistikas funkcijas, ir tiesīga sargāt savus informācijas avotus. ${ }^{44}$ Kaut arī no žurnālista definīcijas angliskā tulkojuma varētu domāt, ka būtiska ir informācijas izplatīšana ar masu informācijas līdzekḷa starpniecību, juridiskajā literatūrā norādīts, ka "medija” koncepts paredz tikai nepieciešamību pēc minimālām regularitātes prasībām informācijas izplatīšanā. Tādējādi Beḷgijā žurnālista statuss un tiesības sargāt savus informācijas avotus attiecas ne tikai uz profesionāliem žurnālistiem, bet arī uz tādām personām kā, piemēram, blogeri. ${ }^{45}$

Arī İrijas Augstākā tiesa ir atzinusi, ka blogeris ir pielīdzināms žurnālistam un viņam ir tiesības aizsargāt savus informācijas avotus. ${ }^{46}$ Tiesa atzina, ka blogera darbības, pētot situāciju un rakstot par reliǵiskiem kultiem, ir uzskatāmas

37 Rožukalne A. Sauciet mani par žurnālistu! Pieejams: http://providus.lv/article/sauciet-mani-parzurnalistu [aplūkots 06.03.2020.].

${ }^{38}$ Freedom of Expression and Protection of Journalistic Sources. International legal research group. Pieejams: https://files.elsa.org/AA/LRG_FoE_Final_Report.pdf [aplūkots 06.03.2020.].

39 Code du travail [Francijas Darba likums]. Pieejams: https://www.legifrance.gouv.fr/affichCode.do?i dSectionTA=LEGISCTA000006189947\&cidTexte=LEGITEXT000006072050\&dateTexte $=20170613$ [aplūkots 06.03.2020.].

40 The Mass Media Act [Slovēnijas Preses likums]. Pieejams: http://www.rtvslo.si/files/razno/mass_ media_act.pdf [aplūkots 06.03.2020.].

${ }^{41}$ The Union of Journalists in Finland. Pieejams: https://journalistiliitto.fi/en/membership/join-theunion/ [aplūkots 06.03.2020.].

42 The Danish Union of Journalists. Pieejams: https://journalistforbundet.dk/sites/default/files/inlinefiles/DJ-in-english.pdf [aplūkots 06.03.2020.].

43 Beḷgijas konstitucionālās tiesas sprieduma Nr. 91/2006 kopsavilkums. Pieejams: https://www.constcourt.be/cgi/judgments_popup.php?lang=en\&ArrestID=2163 [aplūkots 06.03.2020.].

44 Ibid.

45 Freedom of Expression and Protection of Journalistic Sources. International legal research group.

46 İrijas Augstākās tiesas 18.09.2012. spriedums lietā Cornec v. Morrice \& Ors, IEHC 376, para. 65-68. 
par "sabiedrības viedokḷa izglītošanu" un būtu pielīdzināmas tradicionālo mediju darbībai. Attiecīgi tiesa secināja, ka blogera tiesības turpmāk saṇemt sabiedrībai svarīgu informāciju no avotiem varētu tikt apdraudētas, ja tiesa liktu atklāt viņa informācijas avotus. ${ }^{47}$

Tādējādi, ņemot vērā šajā rakstā veikto žurnālista jēdziena analīzi atbilstoši Konvencijas izpratnei, kā arī Eiropas Padomes izteikto aicinājumu dalībvalstīm piemērot funkcionālo definīciju, ${ }^{48}$ autores ieskatā būtu nepieciešams Latvijā normatīvā līmenī izškşirties par labu funkcionālajai definīcijai, izstrādājot skaidrus kritērijus, pēc kuriem fizisku personu varētu uzskatìt par žurnālistu ar visām tiesībām un pienākumiem, kas izriet no šì statusa. Vienlaikus nebūtu samērīgi prasīt atzìtiem žurnālistiem, kuri jau šobrīd atbilst Preses likuma definīcijai, katrreiz no jauna pierādīt savu žurnālista statusu, tādēḷ būtu nepieciešams grozìt spēkā esošo žurnālista definīciju, kombinējot abas teorijas - gan funkcionālo, gan institucionālo.

\section{Kopsavilkums}

1. Pastāv divas galvenās žurnālistu definēšanas teorijas - institucionālā un funkcionālā. Būtiskākā atšķirība starp šìm teorijām ir apstāklī, vai persona, kas veic žurnālista profesionālos pienākumus, strādā kādā medijā vai ir piederīga profesionālajai organizācijai. Eiropas Padome aicina dalībvalstis piemērot funkcionālo žurnālista definīciju, saskaṇā ar to par žurnālistu tiek uzskatīta ikviena persona, kas veic žurnālistam raksturīgās funkcijas un pienākumus. Atbalsts funkcionālās definīcijas piemērošanai ir saskatāms arī ECT praksē. Tāpat arī atsevišķas aplūkotās Eiropas Padomes dalíbvalstis (Francija, Slovēnija, Somija, Dānija, Beḷgija) ir mēǵinājušas rast līdzsvaru starp institucionālo un funkcionālo pieeju.

2. Šobrīd Latvijā normatīvi nostiprinātā žurnālista definīcija atbilst institucionālajai teorijai, kas nepamatoti sašaurina to personu loku, kuras varētu tikt atzìtas par žurnālistiem. Tādēḷ nepieciešams izstrādāt jaunu žurnālista definīciju, ņemot vērā žurnālista funkcijas un ìpašo lomu demokrātiskā sabiedrībā. Definīcijas pamatā vajadzētu būt abām teorijām - gan funkcionālajai, gan institucionālajai.

3. Lai persona varētu tikt atzīta par žurnālistu un paḷauties uz tiesībām aizsargāt savus informācijas avotus, jākonstatē regulāra vai profesionāla iesaiste informācijas vākšanā vai izplatīšanā sabiedrībai par tai būtiskiem jautājumiem. Turklāt jāievēro tādi atbildīgas žurnālistikas pamatprincipi kā pienākums rīkoties labā ticībā, pamatoties uz patiesiem faktiem, sniegt uzticamu un precīzu informāciju, kā arī darboties saskaņā ar žurnālistikas ètiku. Savukārt personas datu apstrādes kontekstā EST izvirzìtās prasības privilēgijas piešķiršanai ir zemākas, jo šo privilēǵiju var piešķirt jebkurai personai, kuras rīcības vienīgais mērḳis ir sniegt sabiedrībai informāciju, viedokḷus vai idejas ar jebkāda izplatīšanas līdzekḷa palīdzību. Tādējādi secināms, ka šobrīd nav pamata piemērot vienotu žurnālista definīciju attiecībā uz visām žurnālistu privilēgijām.

47 İrijas Augstākās tiesas 18.09.2012. spriedums lietā Cornec v. Morrice \& Ors, IEHC 376, para. 66.

${ }^{48}$ Recommendation $\mathrm{CM} / \mathrm{rec}$ (2011) 7 of the Committee of Ministers to member states on a new notion of media. 